AIR COMMAND AND STAFF COLLEGE

AIR UNIVERSITY

\title{
UNIQUE CAPABILITIES: U.S. MILITARY INVOLVEMENT IN SUB-SAHARAN AFRICA
}

\author{
by \\ Anthony M. Packard, Major, USAF \\ A Research Report Submitted to the Faculty \\ In Partial Fulfillment of the Graduation Requirements
}

Advisor: Major Paul Clarke

Maxwell Air Force Base, Alabama

March 2002

Distribution A: Approved for public release; distribution unlimited. 


\section{Report Documentation Page}

Form Approved OMB No. 0704-0188

Public reporting burden for the collection of information is estimated to average 1 hour per response, including the time for reviewing instructions, searching existing data sources, gathering and maintaining the data needed, and completing and reviewing the collection of information. Send comments regarding this burden estimate or any other aspect of this collection of information,

including suggestions for reducing this burden, to Washington Headquarters Services, Directorate for Information Operations and Reports, 1215 Jefferson Davis Highway, Suite 1204, Arlington

VA 22202-4302. Respondents should be aware that notwithstanding any other provision of law, no person shall be subject to a penalty for failing to comply with a collection of information if it

does not display a currently valid OMB control number.

\begin{tabular}{|l|l|l}
\hline 1. REPORT DATE & 2. REPORT TYPE & 3. DATES COVERED \\
\hline 4. TITLE AND SUBTITLE & N/A & - \\
Unique Capabilities: U.S. Military Involvement In Sub-Saharan Africa & 5a. CONTRACT NUMBER \\
\cline { 2 - 3 } & 5b. GRANT NUMBER \\
\cline { 2 - 3 } & 5c. PROGRAM ELEMENT NUMBER \\
\hline 6. AUTHOR(S) & 5d. PROJECT NUMBER \\
\cline { 2 - 2 } & 5e. TASK NUMBER \\
\cline { 2 - 3 } & 5f. WORK UNIT NUMBER \\
\hline 7. PERFORMING ORGANIZATION NAME(S) AND ADDRESS(ES) & $\begin{array}{l}\text { 8. PERFORMING ORGANIZATION } \\
\text { Air UnPORT NUMBER }\end{array}$ \\
\hline 9. SPONSORING/MONITORING AGENCY NAME(S) AND ADDRESS(ES) & 10. SPONSOR/MONITOR'S ACRONYM(S) \\
\cline { 2 - 3 } & $\begin{array}{l}\text { 11. SPONSOR/MONITOR'S REPORT } \\
\text { NUMBER(S) }\end{array}$
\end{tabular}

12. DISTRIBUTION/AVAILABILITY STATEMENT

Approved for public release, distribution unlimited

13. SUPPLEMENTARY NOTES

14. ABSTRACT

15. SUBJECT TERMS

16. SECURITY CLASSIFICATION OF:

\begin{tabular}{c|c|c|}
$\begin{array}{c}\text { a. REPORT } \\
\text { unclassified }\end{array}$ & $\begin{array}{c}\text { b. ABSTRACT } \\
\text { unclassified }\end{array}$ & $\begin{array}{c}\text { c. THIS PAGE } \\
\text { unclassified }\end{array}$ \\
\hline
\end{tabular}

17. LIMITATION OF
ABSTRACT
UU

\begin{tabular}{c|l}
$\begin{array}{c}\text { 18. NUMBER } \\
\text { OF PAGES } \\
\mathbf{4 0}\end{array}$ & 19a. NAME OF \\
& \\
&
\end{tabular}




\section{Disclaimer}

The views expressed in this academic research paper are those of the author and do not reflect the official policy or position of the US government or the Department of Defense. In accordance with Air Force Instruction 51-303, it is not copyrighted, but is the property of the United States government. 


\section{Contents}

Page

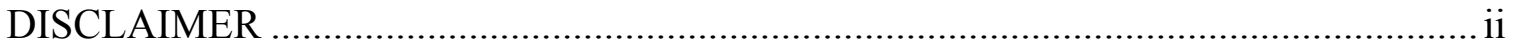

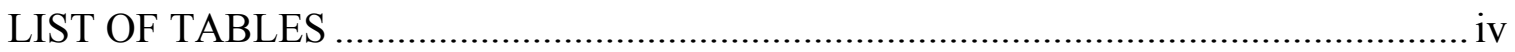

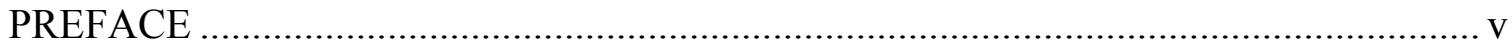

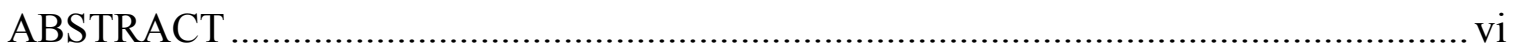

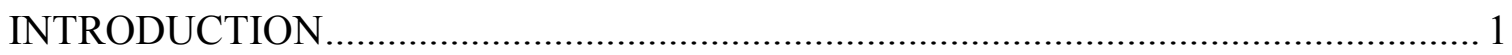

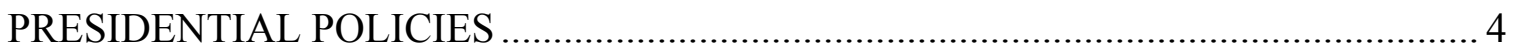

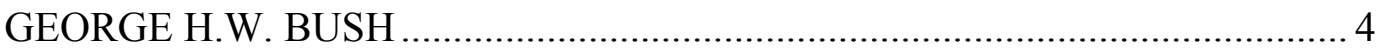

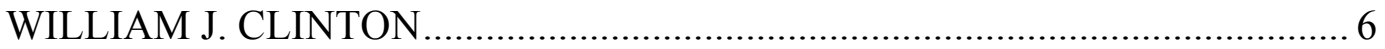

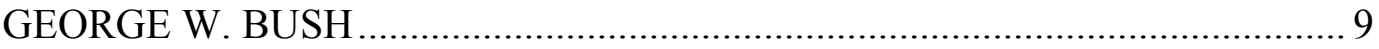

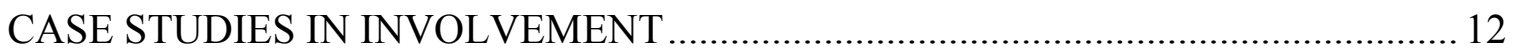

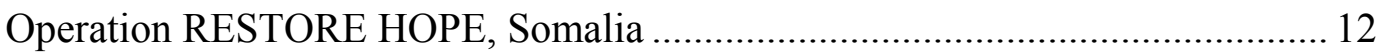

Operation SUPPORT HOPE, Democratic Republic of Congo ............................. 14

Operation GUARDIAN ASSISTANCE, DRC ................................................ 15

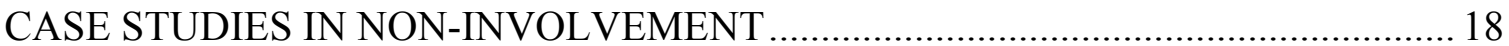

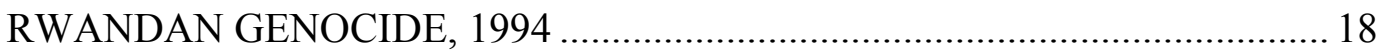

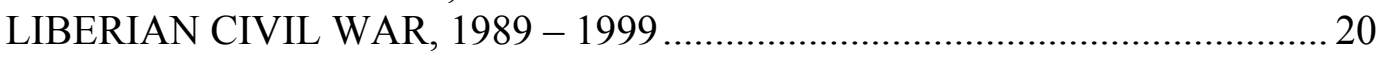

BUILDING AND APPLYING A MODEL FOR PREDICTIVE ANALYSIS ................ 24

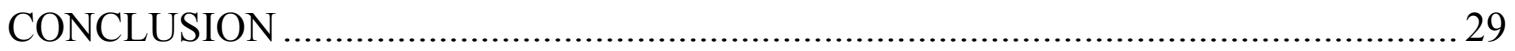

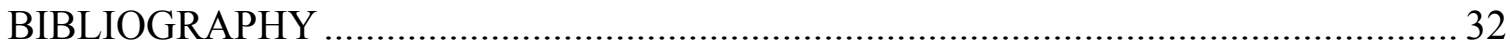




\section{List of Tables}

Page

Table 1 Predictive Model Applied to Potential HE Situations....................................... 27 


\section{Preface}

I undertook this research project to further my own knowledge about United States military involvement in Africa in the post-Cold War period. I had originally hoped to offer the military planners in European Command (EUCOM) and Special Operations Command (SOCOM) a model on which to base indications and warning of likely humanitarian emergencies that forces within their commands may be called to respond to. After underestimating the scope of that project, I hope my predictive analysis model prompts further research into one or all of the variables, to increase the time between an actual or potential HE situation and the time those military planners are given to propose possible American military courses of action.

I want to thank Major Paul Clarke who advised me throughout this project, keeping me on task and on schedule. I also want to thank the library staff at the Air University Library, Maxwell AFB, for their repeated assistance in finding relevant materials around which I could turn my desire to build a model into reality. 
AU/ACSC/089/2002-03

\section{Abstract}

Sub-Saharan Africa has endured frequent and large-scale humanitarian emergencies (HE) of both the natural and man-made variety, and further HE in the region are likely. It is also likely that the United States military will become involved to prevent or alleviate some of these HE, as with Somalia in 1992. In other circumstances, the military will not be used even though it seems like the best (or only) means available, as with the Rwandan genocide of 1994 . For the military planner this poses a dilemma: under what circumstances will the United States response to a HE in Sub-Saharan Africa involve military forces, and what missions will those forces be tasked to carry out? This paper attempts to predict—not prescribe — the answer to this dilemma.

The methodology will first examine the foreign policies of the post-Cold War presidents. Next, specific cases will illustrate how their policies were applied to HE in Sub-Saharan Africa, in both cases of military involvement and noninvolvement. From these cases the presence of five variables indicates when the United States is most and least likely to use its military forces to respond to African HE. The variables are: the likelihood of a permissive environment for the military forces, the need for the U.S. military's unique capabilities, the ability to obtain reliable information about the situation, the estimated duration of a military response, and the relative timing of the HE.

Applying those variables to African countries with a high potential for a new HE, the situation in Angola demonstrates the highest likelihood for United States military action. 


\section{Chapter 1}

\section{Introduction}

The early 1990s brought two significant events that would shape US foreign policy as it approached the new millennium. The first was the end of the Cold War. This brought to a close a fifty-year period of zero-sum international relations in a bipolar world, in which the Soviet Union and the United States used aid, trade, and surrogate militaries in a competition to spread their ideological principles to the corners of the earth. The second significant event was the Persian Gulf War, which saw the United States assemble a multinational military coalition that carried out a United Nations mandate to overturn Iraq's invasion of Kuwait. These two events demonstrated that the United Nations could finally shake off years of inaction in the world's trouble spots, because its two most powerful member states - both of whom wielded veto power over UN Security Council initiatives at international involvement — were determined to forge a more constructive relationship with each other.

With this newfound freedom of action, the Security Council broke out of its confinement of traditional peace keeping operations and into the riskier world of peace making operations. US presidents, proclaiming foreign policies of new world orders and aggressive multilateralism, readily participated in this new category of United Nations

operations in the former Yugoslavia and Somalia. The United States soon discovered, 
however, that peace keeping and peace making are entirely different, the latter often requiring numerous and well-armed military forces in combat-like situations. Unfortunately, the scenarios that necessitate peace making operations are often accompanied by humanitarian emergencies (HE). These are acute, man-made or natural disasters that impose severe or widespread suffering on a population, in a country where the ruling government is unwilling or unable to respond to mitigate that suffering. Perhaps no area has had as many HE — and on such a large scale — as Sub-Saharan Africa. Given the levels of disease, civil war, and susceptibility to natural disasters from floods to droughts that many Sub-Saharan African countries face today, further HE are very likely.

It is also likely that the United States will feel compelled to assist in preventing or alleviating HE in Sub-Saharan Africa, as it has done previously in Somalia, Democratic Republic of Congo, and Mozambique. In other circumstances, the military will not be considered even though it seems like the best (or only) means available. The Rwanda genocide of 1994 and the decade-long Liberian civil war are in this category. For the military planner this poses a dilemma: under what circumstances will the US response to a HE in Sub-Saharan Africa involve military forces, and what missions will those forces be tasked to carry out?

This paper attempts to predict—not prescribe—when the United States is likely to employ military forces to respond to a HE in Sub-Saharan Africa, whether natural or man-made. To qualify this further, the military response must be aimed at preventing or alleviating the emergency and the accompanying suffering. Under this constraint, a noncombatant evacuation operation (NEO) is excluded. The purpose of a NEO is to evacuate American civilians from the HE situation, not stop the event from occurring. 
The methodology will first examine the foreign policies of the three post-Cold War presidents, George H.W. Bush, William Clinton, and George W. Bush. Next, specific cases will be examined to illustrate how and when each president employed military forces to relieve HE in Sub-Saharan Africa. It is equally necessary to examine cases where the "opportunity" existed to use the military to respond to a humanitarian emergency, but the decision was made to respond in other ways, or not at all.

From these cases patterns will emerge in the application of US military power in HE situations in Sub-Saharan Africa. Comparing these cases will demonstrate what characteristics of a HE increase the likelihood that the US response will include military forces, and what those forces will be tasked to accomplish. The emerging model will then be applied to several countries in Sub-Saharan Africa to identify which ones exhibit all or most of those characteristics. Although the region contains more than 45 countries, the model will analyze conditions in six potential "hot spots": Angola, Cote d'Ivoire, Democratic Republic of Congo, Nigeria, Sudan, and Uganda.

To reiterate, this research is not designed to be prescriptive, i.e. it does not intend to recommend in which countries' HE the United States should respond militarily. Its purpose is predictive, to show which countries exhibit the greatest potential for a HE that the United States will respond to militarily, and what that response is likely to include. 


\section{Chapter 2}

\section{Presidential Policies}

\section{GEORGE H.W. BUSH}

President George H.W. Bush's administration had the unique opportunity of building America's first post-Cold War foreign policy. Shortly after he took office the Iron Curtain was dismantled in Romania, Hungary, and even Germany. One year later, he was faced with determining the American response to Iraq's invasion of Kuwait. With the previously unimaginable support of the Soviet Union, President Bush was able to act through the UN Security Council to condemn Iraq's aggression, then assemble a multinational military coalition to overturn it by force. President Bush clearly saw a greater role for the UN in international relations and within US foreign policy, as he said:

Now we see the United Nations beginning to act as it was designed, freed from the superpower antagonisms that often frustrated consensus, less hobbled by the ritualistic anti-Americanism that so often weakened its credibility... The role of the United Nations in improving the human condition and ameliorating human suffering-development, aid to refugees, education, disaster relief — will continue to attract our leadership and our resources. ${ }^{1}$

During the rest of the Bush administration the UN involved itself in a new class of operations aimed at peace making. Peace making operations used coercive military force to suppress conflict, creating a de facto cease fire to permit political negotiations and humanitarian operations. ${ }^{2}$ This was a stark contrast to traditional peace keeping 
operations, wherein the warring parties agreed to a cease fire, separated themselves geographically, and allowed armed troops under UN auspices to monitor the truce.

The origin for this type of operation is found in then-Secretary General Boutros Boutros-Ghali's 1992 work, Agenda for Peace, in which he stated, "United Nations operations in areas of crisis have generally been established after the conflict has occurred. The time has come to plan for circumstances warranting preventive deployment, which could take place in a variety of instances and ways." ${ }^{3}$ If preventive deployment failed to prevent the outbreak of violence, Agenda called on the United Nations to take collective military action under Chapter VII to contain and resolve interor intrastate conflicts. The Bush administration agreed with this principle.

President Bush sought to develop a modern U.S. policy for participating in the United Nations' modern peace keeping and peace making operations and began deliberations on what would become National Security Directive (NSD) 74. President Bush favored designating and training US forces specifically for peace keeping and peace making operations. Several members of his administration disagreed with the concept.

President Bush's most ardent opponents were found within the Pentagon. The Department of Defense did not want to divert resources to these nebulous activities whose relation to the national security interests they doubted. Then-Chairman of the Joint Chiefs of Staff Colin Powell, no doubt colored by his experience leading soldiers into the Vietnamese jungles to pursue vague objectives, was firmly opposed to using the American military for these missions.

Faced with opposition from his senior advisors, President Bush backed away from the aggressive US role in UN operations he first sought. In November 1992 he signed 
NSD 74, Peace Keeping and Emergency Humanitarian Relief Policy. This NSD committed the United States to "consider" contributing those unique capabilities possessed by the military that would directly increase the likelihood for success. The directive marked the introduction of the concept of unique capabilities, which would become the policy of last resort for presidents who could not form consensus for stronger US commitment. The unique capabilities envisioned in NSD 74 included strategic lift, logistics, communications, intelligence, and possibly combat engineering-but not combat personnel or equipment. ${ }^{4}$ Having debated the peace making policy for over a year, President Bush left office within 60 days of signing NSD 74, but not before committing US troops to peace making operations in Somalia. The man who succeeded him sought even greater United States participation in UN operations.

\section{WILLIAM J. CLINTON}

President William Clinton had strong motivations for taking up the policy debate almost as soon as he took office. First, he conducted his campaign by emphasizing his domestic — not foreign — policy. As Sarah Sewall of the Carr Center for Human Rights Policy wrote, "Clinton sought expanded United Nations involvement as a way to reduce US security costs" in places such as Somalia and the former Yugoslavia. Only by making the UN more capable of conducting the more aggressive peace making operations proposed in Agenda for Peace could President Clinton justify scaling back US participation in those operations.

The president had international motivations as well. He formulated a policy of aggressive multilateralism, in which the United States would advocate United Nations involvement in preventive diplomacy and in peace making operations where such 
involvement could stop humanitarian emergencies, a policy criticized as "the foreign policy of Mother Theresa." ${ }^{6}$ This policy was Presidential Decision Document (PDD) 25.

The debate for PDD 25 began in 1993 and lasted about a year, but in that time a deadly battle occurred in Mogadishu, Somalia. There, 18 US servicemen were killed supporting — but operating outside of - a UN mandated peace making mission. Many of the president's advisors favored the new forward leaning United Nations where domestic and/or congressional support existed and where US forces were needed for mission success or to get other countries to commit forces. ${ }^{7}$ The Pentagon chiefs, stinging from Mogadishu, disagreed vehemently with the early tone of PDD 25.

Still-Chairman of the Joint Chiefs of Staff General Powell made his opposition to the use of US combat forces for UN peace making operations - regardless of their underlying goal of stemming a humanitarian emergency—clear when he said, "As long as I am Chairman of the Joint Chiefs of Staff, I will not agree to commit American men and women to an unknown war, in an unknown land, for an unknown cause, under an unknown commander, for an unknown duration." ${ }^{\prime 8}$ The President accepted General Powell's position as final. The resulting PDD 25 backed away from its earlier enthusiastic use of the military and instead said: United States forces would be committed only if necessary for mission success, when the consequences of inaction were unacceptable, where the objectives were clearly defined, and where the risks to those troops were clear and acceptable. ${ }^{9}$ This policy supported aggressive multilateralism by the United Nations, but not necessarily with US combat forces.

The experience in Somalia quickly dampened the enthusiasm for military force in peace making operations, even in the presence of significant human suffering. Within 
months of the United States military's withdrawal from Somalia, Sub-Saharan Africa saw its next HE, the orchestrated murder of hundreds of thousands of Rwandan civilians. The United States committed no forces either to halt what even President Clinton would later admit was genocide. Anyone studying the Rwandan situation would have asked, "was not the cost of inaction unacceptable?" Apprehensive to apply the litmus tests contained within PDD 25, the Clinton Administration clearly needed an Africa policy it could actually follow. It found one in regionalism.

Regionalism sought to redesign African policy from a "one size fits all" model to one based on tailored strategies from various regions of the continent. America had common security concerns across Sub-Saharan Africa, and according to Assistant Secretary of State for African Affairs Susan Rice these were combating terrorism, international crime, narcotics, weapons proliferation, and disease. ${ }^{10}$ Within those regions the United States would look for African solutions to African problems. The United States would contribute its unique capabilities to respond to crises, but those instances would be few and would not involve combat forces. The epitome of the application of this policy was the African Crisis Response Initiative (ACRI).

Through the ACRI, the United States expended over \$15 million annually since 1996 to train militaries of several African countries in aspects of United Nations peace keeping: refugee protection, humanitarian assistance, command and control, and logistics. These militaries have formed the basis of African regional forces acting under the guidance of the regional actors such as the South African Development Council and the Economic Community of West African States (ECOWAS); several ACRI recipients have undertaken operations in Sierra Leone and Liberia. 
The US commitment to training and equipping) African militaries through ACRI reveals the final Clinton security policy on the region—virtual presence. By the Clinton administration's second term it was clear that under almost no circumstances would the United States again commit combat forces for peace keeping in Sub-Saharan Africa. America would further its strategic interests in the region by applying its unique capabilities to support regional actors. Those unique capabilities excluded combat forces, which other United Nations or regional members could provide.

\section{GEORGE W. BUSH}

Although this President Bush has been in office just over one year, he has already reevaluated his initial policy on Sub-Saharan Africa. That policy began inauspiciously when during a presidential debate then-Texas Governor Bush answered questions on his proposed involvement in African nation building activities:

Africa's important. And we've got to do a lot of work in Africa to promote democracy and trade. It's an important continent. But there's got to be priorities. And the Middle East is a priority for a lot of reasons as is Europe, and the Far East, and our own hemisphere. Those are my four top priorities should I be the president. It's not to say we won't be engaged [in Africa], and working hard to get other nations to come together to prevent atrocity. I thought the best example of handling a situation was East Timor when we provided logistical support to the Australians; support only we can provide. I thought that was a good model. But we can't be all things to all people in the world. ${ }^{11}$

Several policy positions were revealed in this answer. First, President Bush preferred to support regional or international engagement to prevent or halt humanitarian emergencies in Africa. This was evident by the $\$ 50$ million and ten weeks spent by US Army forces training and equipping Nigerian combat forces about to undertake peace making operations in Sierra Leone on behalf of ECOWAS. ${ }^{12}$ Second, if the president did commit the military, it would be to provide unique capabilities not possessed by other 
participating militaries. If one assumes President Bush would model future military engagements on the East Timor example, unique US capabilities would include heavy lift, logistical planning and movement, intelligence, reliable communications, and civil affairs (protecting internally displaced persons, establishing habitable conditions, etc). ${ }^{13}$

President Bush's Secretary of Defense, Donald Rumsfeld, seems to have clarified Africa's place in the new administration's security view of the world in the 2001 Quadrennial Defense Review. In it Rumsfeld cites the enduring national interests as "precluding hostile domination of critical areas, particularly Europe, Northeast Asia, the East Asian littoral, and the Middle East and Southwest Asia" and "peace and stability in the Western Hemisphere." ${ }^{14}$ There is no direct mention of Africa except as an area of porous borders from where transnational threats such as terrorism can be launched against America. From this one can reason that unless a situation in Sub-Saharan Africa directly impacts the national interests, this administration will respond by supporting regional or international efforts with unique US military capabilities.

Thus far this paper has addressed only the policies of the post-Cold War presidents toward military involvement in Sub-Saharan African humanitarian emergencies. It is now appropriate to examine actual HE to learn when and how these policies were applied and — just as importantly—when they were not. Since America's operations in Somalia influenced the involvement vs. non-involvement arguments for each president, it will be examined first.

\section{Notes}

${ }^{1}$ George Bush, National Security Strategy of the United States, 1991 - 1992 (Washington, D.C.: Brassey's (US) Inc., 1991), 50.

${ }^{2}$ Pamela L. Reed, J. Matthew Vaccaro, and William J. Durch, Handbook on United Nations Peace Operations (Washington, D.C.: Henry L. Stimson Center, 1995), 3. 


\section{Notes}

${ }^{3}$ Boutros Boutros-Ghali, Report of the Secretary-General: An Agenda for Peace, Preventive Diplomacy, Peace Making and Peace Keeping, Summit Meeting of the Security Council, 1992, Section 28, on-line, Internet 16 January 2002, available from http://www.un.org/Docs/SG/agpeace.htm.

${ }^{4}$ National Security Directive 74, Peace Keeping and Emergency Humanitarian Relief Policy, 24 November 1992.

${ }^{5}$ Sarah Sewall, "U.S. Policy and Practice Regarding Multilateral Peace Operations," Carr Center for Human Rights Policy Working Paper 01-3, on-line, Internet, 1 February 2002, available from http://www.ksg.harvard.edu/cchrp/web/working/20papers/PKO.pdf.

${ }^{6}$ Michael Mandelbaum, "Foreign Policy as Social Work," Foreign Affairs Jan/Feb 1996: 20.

${ }^{7}$ William J. Durch, ed., UN Peacekeeping, American Policy, and the Uncivil Wars of the 1990's (N.Y.: St. Martin's Press, 1996), Table 2.1.

${ }^{8}$ Ivo H. Daalder, "Knowing When to Say No: the Development of U.S. Policy for Peace Keeping," in UN Peacekeeping, American Policy, and the Uncivil Wars of the 1990 's (N.Y.: St. Martin's Press, 1996), 43.

${ }^{9}$ Presidential Decision Directive 25, U.S. Policy on Reforming Multilateral Peace Operations, 4 May 1994, on-line, Internet, 3 January 2002, available from http://www.fas.org/irp/offdocs/pdd25.htm.

${ }^{10}$ Assistant Secretary of State for African Affairs Susan Rice, "Address to Columbia University," New York, N.Y., 20 October 1998, on-line, Internet, 12 March 2002, available from http://allafrica.com/stories/199810290188.htm.

${ }^{11}$ George W. Bush remarks during presidential debate at Wake Forest University, May 2000, on-line, Internet, 7 February 2002, available from http://www.issues2000.org/George_W_Bush_Foreign_Policy.htm.

12 Statement by Peter R. Chaveas before the United States Senate Committee on Foreign Relations, 11 July 2001, on-line, Internet, 28 January 2002, available from http://www.uspolicy.be/issues/AFRICA/s1071201.htm.

${ }^{13}$ Address to Air Command and Staff College by military planner for Pacific theater operations, January 2002.

${ }^{14}$ Donald Rumsfeld, Quadrennial Dense Review, (Washington, D.C.: Office of the Secretary of Defense, 20 September 2001), 2. 


\section{Chapter 3}

\section{CASE STUDIES IN INVOLVEMENT}

\section{Operation RESTORE HOPE, Somalia}

Somalia is situated on the East Coast of Africa, the "Horn of Africa." A one-time colony divided between Italy and Great Britain, the population of Somalia shares a religion (Sunni Islam), an ethnicity, and a language. ${ }^{1}$ In 1991, however, the Somalis were divided between supporters of the ruler, Mohamed Siad Barre, and a confederation of opposition groups. When Barre was overthrown, the confederation splintered into factions that engaged in a bloody struggle to fill the power vacuum.

Atrocities were committed on Somali civilians by each of the factions, but the scorched earth policy of Ali Mahdi, leader of the national congress, combined with an illtimed drought rendered much of Somalia's most fertile agricultural land useless. The International Committee of the Red Cross was clear that a humanitarian emergency was imminent; they reported that two million Somalis were at immediate risk of starvation. ${ }^{2}$

The UN's response came early in 1992: a humanitarian intervention aimed at getting food to the masses while protecting them from further victimization by the warring factions. Unfortunately, according to Algerian Ambassador Mohamed Sanhoun, Special Representative to the Secretary General for the Somalia operation, the logistics system created to deliver and distribute the food was so lacking that its pace of distribution was 
one-third that of the Red Cross. ${ }^{3}$ The UN Security Council dispatched a force of 6,000 to protect the deliveries. Six months later, the United States joined the effort to increase its chances of success.

In August 1992, President Bush initiated Operation PROVIDE RELIEF (OPR), a humanitarian airlift conducted by the US Air Force operating out of Kenya. At the outset of OPR, military forces of other nations protected the distribution routes. The Bush administration was pressed by numerous relief agencies to take more action to relieve the underlying causes of the starvation, lest the situation worsen as soon as the airlift ceased. After months of debate within the National Security Council, President Bush launched Operation RESTORE HOPE.

RESTORE HOPE expanded the mission in Somalia to include securing and protecting the port at Mogadishu, protecting the distribution centers, and preventing the "armies" of Somali warlords from commandeering the relief supplies for their own loyal supporters. As the presidency transitioned from the Bush to Clinton administrations, Operation RESTORE HOPE transitioned as well.

Somalia provided the perfect test ground for President Clinton's aggressive multilateralism. The president enlarged the American military presence to 25,000 personnel, with over 1,000 special operations-capable forces. ${ }^{4}$ US forces continued to protect the relief supplies and distribution centers, but when that became increasingly difficult due to armed attacks on the relief convoys, President Clinton authorized direct action to enforce a peace.

Although General Mohamed Farah Aideed had led the army that ousted Siad Barre, he had since become the greatest barrier to an effective United Nations peace making 
operation. His forces harassed the relief efforts, and he refused to take part in power sharing negotiations to restore governance to Somalia. Acting outside-but with the knowledge and agreement of - the Secretary General and the UN Operation in Somalia, US special forces engaged in a mission in October 1993 to remove Aideed from the Somali political scene. The mission went horribly wrong from many stand-points, including its impact on aggressive multilateralism in African intrastate conflicts.

The first major foreign policy endeavor of the Clinton administration became a failure almost as soon as the bodies of dead American servicemen were dragged through Mogadishu's streets in full view of the international media. Before that battle administration spokespersons proclaimed that the general interests the United States had in the Somali situation (i.e. ending the starvation) were sufficient to warrant the large military commitment. The ground truth of Somalia and other United Nations operations in the former Yugoslavia eroded domestic support for that position. The application of PDD 25 retreated from "whatever it took" to restore stability and end the humanitarian emergency, to providing just those capabilities that only the U.S. military possessed.

\section{Operation SUPPORT HOPE, Democratic Republic of Congo}

The 1994 crisis in Rwanda and its resulting genocide will be discussed below as a case of American non-involvement. For this chapter it is sufficient to point out that due to the Rwandan Hutus' policy of eradicating rival Tutsis, and the latter's revenge as they restored themselves to control of the government, an estimated 2 million Rwandan refugees had left the country. Half of them fled to Goma, Democratic Republic of Congo (DRC). The size and ethnic rivalry of the refugee population quickly overwhelmed the 
DRC's ability to control the situation. By mid-July an estimated 3,000 refugees were dying each day. ${ }^{5}$ President Clinton responded by launching Operation SUPPORT HOPE. Launched in July 1994, Operation SUPPORT HOPE was a humanitarian relief effort aimed at making the Goma refugee camps livable by controlling the outbreak of diseases, providing clean food and water, and restoring security. To do this a joint task force (JTF) took control of Rwandan airspace, improved the camps' facilities, and rebuilt roads leading back to Rwanda. The JTF also established a civil-military operations center (CMOC) to facilitate military awareness of and support to the relief efforts of numerous nongovernmental organizations. The operation lasted just over two months but by its end had significantly reduced the daily mortality rate in the camps, delivered over 3,000 total tons of supplies, and provided 100 million gallons of purified water. ${ }^{6}$ The United States turned over the operation to the United Nations and nongovernmental organizations, only to return two years later to those same camps.

\section{Operation GUARDIAN ASSISTANCE, DRC}

The refugee camps were still filled to capacity in 1996, largely due to fears of retribution to either Tutsi or Hutu who returned to Rwanda. In that year, however, the political situations changed for the better in Rwanda and for the worse - much worse-in the DRC. In the fall of 1996 relief supplies headed to the camps in Goma were cut off due to the DRC's civil war. Meanwhile the Tutsi-led government of Rwanda had restored order to most of the country and created conditions for the repatriation of the refugees in Goma and elsewhere. President Clinton decided to aid in this effort. In November he directed US European Command (EUCOM) to launch Operation 
GUARDIAN ASSISTANCE (OGA) to provide supplies to those still in the camps and encourage the peaceful migration of those refugees wishing to return to Rwanda.

PDD 25 was clearly discernable behind the Commander-in-Chief, European Command (CINCEUR) statement of intent for OGA: "Rapidly assess the situation and recommend usage of unique US military capabilities; complement/supplement designated United Nations/civilian-led agencies, minimizing the requirement for U.S. military forces..."7 The president originally pledged to send in up to 2,000 ground forces to secure delivery of relief supplies. Based on the advice of an advance team, CINCEUR actually deployed a force of less than 500 to augment a Canadian-led response force.

According to Major General Edwin P. Smith, commander of the US Army component of OGA, the military's contribution centered around achieving information superiority concerning the movement and well-being of the refugees. To this end, the army deployed mobile training teams of psychological operations and civil affairs forces to train the Rwandan and DRC militaries on crowd movement and control. To track the progress of the refugees through uninhibited areas, the US Navy and Air Force provided aerial reconnaissance. Other unique capabilities were the logistics to restore the flow of relief supplies and the command, control, and communications (C3) to coordinate military and civilian operations in an environment with negligible infrastructure. No ground combat forces were deployed for security or peace making operations.

Operation GUARDIAN ASSISTANCE provided further insight into the application of PDD 25 in addition to the concept of unique capabilities. According to Secretary of Defense William Perry, United States troops did not deploy until the administration had received assurances from both Rwandan and DRC military leaders that US operations 
would proceed unopposed. ${ }^{8}$ As the operation proceeded, Rwanda and the DRC asked the United States and the United Nations to lessen their presence so that regional militaries could take over. President Clinton obliged. Also, from its outset OGA carried a fourmonth time limit that the United States adhered to. After that, the American military once again withdrew from Sub-Saharan Africa.

\section{Notes}

${ }^{1}$ William J. Durch, "Introduction to Anarchy: Humanitarian Intervention and 'State Building' in Somalia," in UN Peacekeeping, American Policy, and the Uncivil Wars of the 1990's, ed. William J. Durch. (N.Y.: St. Martin's Press, 1996), 313

2 "Country Report Somalia: ICRC Worldwide Consultation on the Rules of War," People on War, 1999, on-line, Internet, 1 February 2002, available from http://www.ifrc.org/icrceng.nsf.

${ }^{3}$ Durch, "Introduction to Anarchy," 316.

${ }^{4}$ R. Jeffrey Smith and Julia Preston, "United States Plans Wider Role in United Nations Peace Keeping," Washington Post, 18 June 1993, on-line, Internet, 1 February 2002, available from http://www.fas.org/irp/offdocs/pdd13.htm.

${ }^{5}$ Air Mobility Command, 1997 Air Mobility Master Plan, October 1996, excerpted, on-line, Internet, 12 March 2002, available from http://wwwcgsc.army.mil/usaf/Courses/AY98-99/500/Excerpts_AMMP.htm.

${ }^{6}$ Ronald R. Cunitz, "Applying Lessons Learned: the U.S. European Command Experience in Funding Operation Support Hope," Armed Forces Comptroller 40 (Win 95): 15.

${ }^{7}$ Edwin P. Smith, "Joint Task Forces and Preemptive Response," Joint Force Quarterly 20 (Aut/Win 98-99): 93.

${ }^{8}$ Alison Mitchell, "US Offers Troops for Mission to Aid Zaire Refugees," New York Times, 14 November 1996. 


\section{Chapter 4}

\section{CASE STUDIES IN NON-INVOLVEMENT}

\section{RWANDAN GENOCIDE, 1994}

In April 1994, Hutu extremists shot down an aircraft carrying Rwandan President

Juvénal Habyarimana as the plane returned to the capital city of Kigali. ${ }^{1}$ They then used broadcast media to blame their rival ethnic group, the Tutsis, for the event and initiate a nationwide effort at ethnic cleansing that made similar activities in the former Yugoslavia pale by comparison. Although accurate casualty figures will never be obtained, the conservative estimate is that Hutus killed 500,000 Tutsis in a three-month period. There was no initial US response, but the UN had no choice but to respond.

When the assassination occurred, the United Nations found itself in the middle of the tumult but insufficient in number and lacking in ability to prevent the killing. In fact, forces of the United Nations Mission in Rwanda (UNAMIR) were among the first victims of the orchestrated chaos, when ten Belgian troops of UNAMIR were killed alongside the Rwandan prime minister they were protecting.

Lieutenant General Romeo Dallaire commanded the 2,500-member strong UNAMIR, whose mission was to implement an agreement integrating Tutsis back into the Hutu-led government (the Arusha Accords). According to Dallaire and others, UNAMIR lacked an intelligence structure to assess accurately the strength, disposition, 
and (most critically) the intentions of the hard-line Hutu element that seemed determined to undermine the Arusha Accords. ${ }^{2}$

UNAMIR forces also lacked the logistics and compatible communications to support deployments out of Kigali and into the smaller towns and countryside. This played a significant part in the murderous scheme. The Hutu extremists first intimidated Tutsi populations to uproot from the cities and take refuge at religious and civic buildings in the smaller towns. With the Tutsis thus concentrated as opposed to intermixed with Hutus as they had traditionally been in Kigali, it was much easier for the Hutu masses to descend on the Tutsis and kill them on the roads and in their "shelters," free from UNAMIR observers.

The contingents that comprised UNAMIR had restrictive rules of engagement that prevented their use of force to stop ethnic violence they did observe. In fact, when violence heated up in the spring of 1994, many contingents pulled their forces from UNAMIR. General Dallaire was left with 450 soldiers, not even enough to keep a lid on Kigali let alone the rural areas that were experiencing the most violence. None of those 450 troops were American, nor was there an independent US military contingent.

Timing likely played a part in President Clinton's decision not to intervene militarily. US forces were aggressively returning control of the international response in Somalia back over to the United Nations, a mere six months after the episode in Mogadishu. The military was also engaged in restoring peace to Bosnia-Herzegovina and was preparing to intervene in Haiti to stem the refugee reflux into Florida. The Rwandan situation at first looked like one the United States could bow out on, given the information available. 
That information did not come from US intelligence sources $^{3}$ but rather from nongovernmental organizations and the international media. Like the UNAMIR forces, these organizations had little capability to penetrate the Hutu extremist groups and discern the truth. Also, few Tutsis made it to refugee camps inside Rwanda to tell their story. Without reliable information the Clinton administration refused to label the Rwandan situation a genocide, a label that might have compelled United States action, ${ }^{4}$ but instead could follow PDD 25, which did not. During a 1998 visit to Kigali, President Clinton expressed the clear vision of hindsight when he said, "We did not immediately call these crimes by their rightful name: genocide."

Summarizing the reasons the United States did not respond militarily in Rwanda in 1994, it appears America did not want to engage with combat forces to separate the sides of a civil war, particularly when those sides were still engaged in active combat. Also, the United States lacked incontrovertible evidence to brand the situation a genocide, so it was not compelled by international treaty to intervene. Finally, there is a matter of timing. The US military was already engaged in significant operations in Somalia and Bosnia, and the proximity in time to the battle in Mogadishu soured American decision makers on most military involvement in Africa.

\section{LIBERIAN CIVIL WAR, 1989 - 1999}

If the United States might have felt compelled to intervene anywhere in Sub-Saharan Africa, it would have been in Liberia, whose existence as a country is "owed" to America's mid-nineteenth century policy of returning freed slaves to the newly formed Liberia. Despite this none of the three post-Cold War presidents committed military 
forces in response to the decade long civil war, except to conduct noncombatant evacuation operations (NEO) on two separate occasions.

Liberia's civil war began on President George H.W. Bush's watch, when in 1989 Charles Taylor initiated a coup to overthrow the US-supported president, Samuel Doe. Forces loyal to Taylor and Doe exchanged bouts of mass killing of noncombatants, usually conducted by one tribe against another. Doe was killed in 1990, but the fighting continued between Taylor and leaders of rival factions. Several peace accords were signed; all were broken. The end result was typical for post-colonial Africa: ten years of civil strife had left at least 100,000 Liberians dead and 1.4 million internally or externally displaced. ${ }^{6}$ Unlike other African HE, however, the international response in Liberia was not led by the United Nations but by a regional entity, ECOWAS, and its military arm, ECOWAS Military Operations Group (ECOMOG).

The 15 nations comprising ECOWAS feared that instability in Liberia would spill over into surrounding countries (that fear was validated in Côte d'Ivoire and Sierra Leone). To prevent that and to overcome the image of a region mired in conflict—and unsuitable for foreign investment—ECOWAS brokered a peace agreement and backed it up with ECOMOG forces.

For years ECOMOG remained incapable of creating a peaceful military climate in which the political climate could improve. Time and time again, ECOMOG found itself outnumbered or lesser equipped than the armed faction it was attempting to disarm and demobilize. The United States responded monetarily, helping to finance ECOMOG operations and postponing Liberia's debt repayments until the situation stabilized. Militarily, the United States became involved only in the NEO. 
Despite its historic ties to Liberia, the United States never considered expanding the military's role beyond NEO. Brent Scowcroft, the elder President Bush's National Security Advisor, expressed sentiments on Liberia shared by the Bush and Clinton administrations: "ECOWAS said 'This is our responsibility' and they have been doing their best to handle what is a terrible situation. If it can be handled by states in the area, then that is how it should be done."

As in Rwanda, US responses to Liberia were impacted by the nature and timing of the situation. Although rebel elements operated in several Sub-Saharan African nations, the conflict was fundamentally an internal struggle for the control of Liberia. Not even the New World Order called for American intervention into the internal affairs of another country, particularly one not trying to split into other countries, as did Yugoslavia. As for timing, just as the situation turned questionable for the first NEO, Iraqi forces invaded Kuwait and started the Gulf War. Liberia slipped into the shadows of American interests.

The US experience in Somalia colored the response to Liberia's problems. First, as in Somalia, there was no peace to keep, restore, or make in Liberia. In fact, the violence and political turbulence were spreading across the region. A US military intervention would have been opposed and would have led to American casualties on the ground in Africa again. Second, a regional actor, ECOMOG, had already committed military forces; Nigeria had committed a large number of American-trained (via ACRI) and equipped ground troops. ECOWAS members wanted more financial or materiel support, but few wanted to see the introduction of US combat forces into "their" region. ${ }^{8}$

Finally, there were no unique capabilities US forces could have offered in Liberia. ECOMOG became capable of handling the logistics of its operation and had shown 
ability to deploy throughout the country. They had extensive contacts with all the warring factions, so their intelligence networks were in place. Their downfall lay in their lack of absolute numerical superiority throughout Liberia and the surrounding countries, and in the complete unwillingness of the Liberian parties to end the fighting. The United States had little to offer the situation except raw numbers of combat troops. The Clinton administration never seriously considered doing so.

\section{Notes}

${ }^{1}$ Scott R. Feil, Preventing Genocide: How the Early Use of Force Might Have Succeeded in Rwanda (N.Y.:Carnegie Corporation of New York, 1998),1.

${ }^{2}$ Feil, 5.

3 The author discovered no unclassified references to what (if anything) the intelligence community knew about the Rwandan situation in April 1994.

${ }^{4}$ Under the United Nations Genocide Convention, signatories (including the United States) are compelled to prevent acts of genocide when they become aware of them. "Convention on the Prevention and Punishment of the Crime of Genocide," United Nations Treaty Collection, October 2001, on-line, Internet, 8 February 2002, available from http://www.unhcr.ch/html/menu3/b/p_genoci.htm.

${ }^{5}$ Ibid.

${ }^{6}$ Lieutenant Colonel Festus B. Aboagye, ECOMOG: a Sub-regional Experience in Conflict Resolution, Management, and Peace Keeping in Liberia (Accra, Ghana: SEDCO Publishing Limited, 1999), 39.

7 Brent Scowcroft, on-line, Internet, 17 February 2002, available at http://www.sas.upenn.edu/African_Studies/Urgent_Action/APIC.

${ }^{8}$ Aboagye, 292. 


\section{Chapter 5}

\section{BUILDING AND APPLYING A MODEL FOR PREDICTIVE ANALYSIS}

Analyzing the cases of US military involvement and non-involvement to stem humanitarian emergencies in Sub-Saharan Africa, one can identify characteristics that make a situation more or less susceptible to that involvement. These are:

1. the likelihood of a permissive environment for United States military forces

2. the need for unique capabilities (lift; logistics; command, control, and communications (C3)); civil affairs; and intelligence, surveillance, and reconnaissance (ISR)) as opposed to combat or police forces

3. the ability to obtain reliable information about the HE on which to base decisions to commit or not commit military forces

4. the estimated duration of a military response

5. the timing in relation to other contingencies

The most important variable appears to be the likelihood of a permissive environment. This is due in no small part to the experiences in Somalia, Bosnia, and other peace making operations, where presidents have had difficulty explaining why American soldiers were lost in situations of peripheral-rather than vital-interest. During operations SUPPORT HOPE and GUARDIAN ASSISTANCE, the governments of the DRC, Rwanda, Angola, and others assured American presidents that they would not interfere with the humanitarian relief efforts, and they did not. When the United States military undertook Operations ATLAS RESPONSE to save victims of the 
Mozambique floods in 2000, the civil war was over and the factions had already disarmed.

Contrast those environments with Liberia in the 1990s, Rwanda in 1994, and Sierra Leone today. The factions were heavily armed and opposed to outside intervention, whether from the United States, United Nations, or African organization. In each case military forces of other countries were attacked during their interventions. Simply put, the factions in these cases caused or manipulated the HE to further their own causes; they were not likely to permit an outside military to halt the HE. Likelihood of opposition is not the only variable in predicting United States military involvement. The necessity to use unique capabilities plays a significant role.

Although the functions performed by ground combat forces are often vital to the success of the operations (such as protecting convoys of relief supplies), none are uniquely American. Rather, the US military is capable of employing its inter- and intratheater airlift, sealift, and ground transportation assets to deliver relief supplies in austere environments. Thanks to satellite-enhanced capabilities, the military can also provide compatible communications equipment to military and nonmilitary units deployed throughout Sub-Saharan Africa. Finally, the global ISR and civil affairs capabilities improve the military's performance in HE situations.

Another significant variable in gauging potential United States military response is the government's access to reliable information about the situation. Sometimes the security or habitability deteriorates so much during a crisis that diplomatic staffs and nongovernmental organizations evacuate the trouble spots. Denied the information from 
these "eyes on the scene," presidents have proven apt not to commit military forces for situations they cannot accurately assess.

The estimated duration of US military involvement appears to be a factor, with presidents more likely to commit to situations that can be resolved in a matter of months. This explains why the military assisted in repatriating Rwandan refugees (which took four months) but not in resettling refugees from other fronts in the DRC civil war.

The fifth significant variable, the relative timing of the HE, cannot be placed into a predictive model. The generalization can be made, though, that if the military is involved in significant operations in those regions specifically mentioned in the QDR, it will be less likely to become involved in Sub-Saharan Africa. This is as much a force size limitation as a foreign policy decision. The military is not sized to undertake multiple smaller scale contingencies without overburdening it. The unique capabilities of strategic lift, C3, and ISR — - all high demand, low density assets—are particularly vulnerable.

Other variables were considered because they were exhibited in some HE but not in others. These were the internal versus international nature of the HE, its cause (manmade or natural), and the number of noncombatants affected by the emergency. The true test of any model, however, is to feed it accurate information and have it "predict" events as they actually occurred. Inclusion of these variables did not enable the model to predict the likelihood of military involvement. For example, a genocide involving 500,000 victims should have crossed any numerical threshold, but it did not prompt military involvement because the scale of most African HE are measured in the millions of victims. And yet, ATLAS RESPONSE in Mozambique aided less than 100,000 civilians. 
It is now time to apply the model to several current situations in Sub-Saharan Africa

that could disintegrate into a humanitarian emergency. The table examines the nature of

potential HE in Angola, Côte d'Ivoire, DRC, Nigeria, Sudan, and Uganda.

Table 1 Predictive Model Applied to Potential HE Situations

\begin{tabular}{|c|c|c|c|c|}
\hline & $\begin{array}{c}\text { Likelihood of } \\
\text { permissive } \\
\text { environment }\end{array}$ & $\begin{array}{l}\text { Need for unique } \\
\text { capabilities }\end{array}$ & $\begin{array}{c}\text { Ability to obtain } \\
\text { reliable } \\
\text { information }\end{array}$ & $\begin{array}{c}\text { Expected duration } \\
\text { of military } \\
\text { involvement }\end{array}$ \\
\hline ANGOLA & $\begin{array}{l}\text { If UNITA pursues } \\
\text { peace after death of } \\
\text { long-time leader Jonas } \\
\text { Savimbi, the U.S. } \\
\text { could "buy" a } \\
\text { permissive } \\
\text { environment with } \\
\text { promises of trade. }\end{array}$ & $\begin{array}{l}\text { Intratheater lift due } \\
\text { to lack of passable } \\
\text { roads in much of } \\
\text { the country's } \\
\text { interior. C3 due to } \\
\text { lack of } \\
\text { infrastructure. } \\
\text { Civil affairs to } \\
\text { entice rank-and- } \\
\text { file UNITA to } \\
\text { disarm. }\end{array}$ & $\begin{array}{l}\text { Depends on } \\
\text { cooperation } \\
\text { between UNITA } \\
\text { and Angolan } \\
\text { government to } \\
\text { maintain a } \\
\text { peaceful situation. } \\
\text { If so, NGOs and } \\
\text { diplomats will } \\
\text { have access to } \\
\text { areas of HE. }\end{array}$ & $\begin{array}{l}\text { Short. Likely U.S. } \\
\text { military response } \\
\text { would include } \\
\text { training in civil } \\
\text { affairs, } \\
\text { construction of C3 } \\
\text { network, and } \\
\text { tactical lift until } \\
\text { roads are rebuilt. }\end{array}$ \\
\hline $\begin{array}{l}\text { CÔTE } \\
\text { d'IVOIRE }\end{array}$ & $\begin{array}{l}\text { Likely in much of } \\
\text { country due to heavy } \\
\text { French influence and } \\
\text { fact that country } \\
\text { prefers peaceful } \\
\text { resolution to divisive } \\
\text { issues. }\end{array}$ & $\begin{array}{l}\text { No. The country's } \\
\text { infrastructure is } \\
\text { largely intact. } \\
\text { Again, French } \\
\text { forces could } \\
\text { provide lift, } \\
\text { logistics, and ISR. }\end{array}$ & Good. & $\begin{array}{l}\text { Short, if any. } \\
\text { Would likely join } \\
\text { French, United } \\
\text { Nations, or } \\
\text { ECOWAS efforts. }\end{array}$ \\
\hline DRC & $\begin{array}{l}\text { Unlikely. DRC has at } \\
\text { least three warring } \\
\text { factions not yet } \\
\text { willing to stop } \\
\text { fighting. Six nations } \\
\text { currently intervening } \\
\text { are split into two } \\
\text { camps; therefore, U.S. } \\
\text { actions would only } \\
\text { favor half of the } \\
\text { actors. }\end{array}$ & $\begin{array}{l}\text { No. DRC situation } \\
\text { requires police } \\
\text { force to restore law } \\
\text { and order and } \\
\text { implement any } \\
\text { cease fire. Also } \\
\text { requires ground } \\
\text { forces to escort } \\
\text { relief convoys into } \\
\text { interior. U.S. not } \\
\text { likely to provide } \\
\text { either. }\end{array}$ & $\begin{array}{l}\text { Not good. Sides } \\
\text { have been } \\
\text { unwilling to stop } \\
\text { fighting, even in } \\
\text { the face of cease } \\
\text { fires. NGOs and } \\
\text { international } \\
\text { contingents have } \\
\text { repeatedly } \\
\text { retreated into the } \\
\text { main cities or } \\
\text { pulled out entirely. }\end{array}$ & $\begin{array}{l}\text { Long. It will take } \\
\text { years for the sides } \\
\text { to implement a } \\
\text { lasting cease fire. } \\
\text { It will take as long } \\
\text { to convince } \\
\text { internally } \\
\text { displaced persons } \\
\text { that they are safe } \\
\text { to return to their } \\
\text { native villages. }\end{array}$ \\
\hline NIGERIA & $\begin{array}{l}\text { If HE is caused by } \\
\text { division of the country } \\
\text { into north and south, } \\
\text { that might create a } \\
\text { demilitarized zone } \\
\text { (DMZ) to separate the } \\
\text { armed forces of each } \\
\text { side. Any action } \\
\text { without a DMZ would } \\
\text { be opposed. }\end{array}$ & $\begin{array}{l}\text { Yes. The } \\
\text { communication, } \\
\text { water, } \\
\text { transportation and } \\
\text { power systems are } \\
\text { underdeveloped, } \\
\text { particularly in the } \\
\text { south-scene of } \\
\text { the most likely } \\
\text { HE. }\end{array}$ & $\begin{array}{l}\text { If the U.S. were to } \\
\text { side with the oil- } \\
\text { rich south (rather } \\
\text { than the } \\
\text { government in the } \\
\text { north), access to } \\
\text { reliable } \\
\text { information would } \\
\text { degrade. }\end{array}$ & $\begin{array}{l}\text { Long. The } \\
\text { partition would not } \\
\text { be smooth or } \\
\text { quick. The south } \\
\text { is currently so } \\
\text { underdeveloped } \\
\text { that any relief } \\
\text { effort would } \\
\text { stretch out over } \\
\text { years. }\end{array}$ \\
\hline
\end{tabular}




\begin{tabular}{|c|c|c|c|c|}
\hline SUDAN & $\begin{array}{l}\text { Unlikely. U.S.-Sudan } \\
\text { relations have been } \\
\text { bad for years. The } \\
\text { significant Muslim } \\
\text { movement is pro-Iran, } \\
\text { anti-U.S. Any } \\
\text { American effort in a } \\
\text { HE in the South } \\
\text { would be militarily } \\
\text { attacked by the } \\
\text { Sudanese government. }\end{array}$ & $\begin{array}{l}\text { The ports are in the } \\
\text { north. Access to } \\
\text { the south would } \\
\text { have to stage } \\
\text { through or over } \\
\text { Kenya or Uganda, } \\
\text { which would be } \\
\text { hesitant. } \\
\text { Therefore, it is } \\
\text { unlikely the U.S. } \\
\text { could deploy its } \\
\text { capabilities in a } \\
\text { nonpermissive } \\
\text { environment. }\end{array}$ & $\begin{array}{l}\text { Good. American } \\
\text { intelligence } \\
\text { agencies have paid } \\
\text { considerable } \\
\text { attention to Sudan } \\
\text { due to its } \\
\text { suspected } \\
\text { sponsoring of } \\
\text { terrorism. Also, } \\
\text { the U.S. could } \\
\text { expect intelligence } \\
\text { support from the } \\
\text { Sudanese Peoples } \\
\text { Liberation Army if } \\
\text { the U.S. were } \\
\text { involved in the } \\
\text { south. }\end{array}$ & $\begin{array}{l}\text { Short if the U.S. } \\
\text { confines its } \\
\text { operations to } \\
\text { humanitarian } \\
\text { resupply of } \\
\text { activities of NGOs. } \\
\text { Any protracted } \\
\text { U.S. presence } \\
\text { would invoke a } \\
\text { military or terrorist } \\
\text { response against } \\
\text { American forces } \\
\text { involved. Long if } \\
\text { the U.S. were to } \\
\text { intervene for peace } \\
\text { keeping between } \\
\text { north and south. }\end{array}$ \\
\hline UGANDA & $\begin{array}{l}\text { Likely. The HE } \\
\text { would probably be } \\
\text { caused by internal } \\
\text { refugees forced to flee } \\
\text { by rebel factions. The } \\
\text { U.S. would side with } \\
\text { the government, who } \\
\text { controls most of the } \\
\text { country. The U.S. } \\
\text { military would most } \\
\text { likely operate out of } \\
\text { bases controlled by } \\
\text { government forces. }\end{array}$ & $\begin{array}{l}\text { No. Most likely } \\
\text { international } \\
\text { involvement would } \\
\text { require ground } \\
\text { forces to separate } \\
\text { the sides, protect } \\
\text { humanitarian } \\
\text { support operations, } \\
\text { etc. The U.S. } \\
\text { would not } \\
\text { contribute ground } \\
\text { forces for these } \\
\text { roles. The U.S. } \\
\text { might train } \\
\text { Ugandan forces for } \\
\text { these roles, } \\
\text { however. }\end{array}$ & $\begin{array}{l}\text { There would be } \\
\text { little U.S. ability to } \\
\text { obtain accurate } \\
\text { information about } \\
\text { regions controlled } \\
\text { by the rebels, since } \\
\text { the U.S. has } \\
\text { supported the } \\
\text { government for } \\
\text { years. The ability } \\
\text { of NGOs to } \\
\text { operate in rebel- } \\
\text { controlled territory } \\
\text { is doubtful. }\end{array}$ & $\begin{array}{l}\text { Short. Unless the } \\
\text { rebels significantly } \\
\text { increase their } \\
\text { abilities, their } \\
\text { control of territory } \\
\text { is probably short- } \\
\text { lived. Therefore } \\
\text { any internal } \\
\text { displacement } \\
\text { would also be } \\
\text { short-lived. }\end{array}$ \\
\hline
\end{tabular}




\section{Chapter 6}

\section{CONCLUSION}

Unfortunately, the United States will probably have a plethora of opportunities to prevent or halt humanitarian emergencies throughout Sub-Saharan Africa. In many of these situations the Bush administration will respond economically, by providing debt relief of outstanding loans and financing the efforts of regional and international actors such as the Organization of African Unity or the United Nations. In other situations the response will be by military proxy, that is, by training and equipping African militaries to intervene in peace keeping or peace making operations. It will do this through ACRI. In still other situations, the United States will call on the unique capabilities of its military forces to alleviate the suffering and/or restore stability.

Of the countries examined above and their most likely HE, the situation in Angola exhibits the characteristics that make U.S. military involvement more likely. If the Union for the Total Independence of Angola (UNITA) pursues a peaceful settlement of its differences with the Angolan government, reintegration of UNITA supporters could proceed smoothly. Consequent involvement by the United States to help the situation would be unopposed. The military could then use its tactical airlift to position supplies and other nations' peace keepers throughout the country, since 80-percent of the country's roads are in disrepair according to the state-owned road construction and 
maintenance company. ${ }^{1}$ The US military also possesses the $\mathrm{C} 3$ to enable nationwide communications to maintain an accurate picture of the operation.

If the HE were caused by nature, such as famine, the environment would still likely be favorable to US military involvement. UNITA is struggling to maintain its supporters, and enabling international relief efforts supported by the United States (supporter of UNITA throughout the Cold War) would boost its image. The US military could use its lift, C3, ISR, and civil affairs forces to protect and steer the population to relief points.

Aside from Angola, Côte d'Ivoire possesses three of the four characteristics used in the model. The only one lacking is the ability to contribute unique capabilities, and that is because the French military would probably provide them. The United States military could be called upon to augment them with intertheater lift, and through ACRI to train and equip ECOWAS militaries for peace enforcement duties.

Sub-Saharan Africa is not the area of utmost importance to the Bush administration, which is generally less disposed to use military forces for peace missions. The one variable impossible to predict is the timing of any African $\mathrm{HE}$ relative to military operations in Europe, the Asian littoral, or the Middle East. The military's involvement in the global war on terrorism (GWOT) will occupy the first priority and the first choice of scarce resources. Of course the GWOT could see the U.S. military responding to HE in Yemen, Tunisia, and Kenya as collateral missions to the primary mission of eliminating international terrorist networks operating in those countries (recall Air Force airdrops of humanitarian daily rations to Afghani civilians in the first phase of the GWOT). The Bush administration may call on the military's unique capabilities for SubSaharan African HE sooner than it would have predicted. 


\section{Notes}

1 "Angola," Regional Surveys of the World: Africa South of the Sahara 2001 (London: Europa Publications, 2000), 189. 


\section{Bibliography}

Aboagye, Lieutenant Colonel Festus B. ECOMOG: a Sub-regional Experience in Conflict Resolution, Management, and Peace Keeping in Liberia. Accra, Ghana: SEDCO Publishing Limited, 1999

Air Mobility Command. 1997 Air Mobility Master Plan, October 1996. On-line. Internet, 12 March 2002. Available from http://www-cgsc.army.mil/usaf/Courses/ AY98-99/500/Excerpts_AMMP.htm.

Alden, Chris. "From Neglect to 'Virtual Engagement': The United States and Its New Paradigm for Africa." African Affairs 99 (2000): 355-371.

Appiah-Mensah, Lieutenant Commander Seth. "Lessons from Liberia." Proceedings (March 200): 66-68.

Boutros Boutros-Ghali. Report of the Secretary-General: An Agenda for Peace, Preventive Diplomacy, Peace Making and Peace Keeping, June 1992. On-line. Internet, 16 January 2002. Available from http://www.un.org/Docs/SG/agpeace.htm.

Brower, Scott E. and Anna Simons. "The ACRI Command and Control Challenge." Parameters (Winter 2000-2001): 118-127.

Bush, George H.W. National Security Directive 74, Peace Keeping and Emergency Humanitarian Relief Policy, 24 November 1992.

Bush, George H.W. National Security Strategy of the United States, 1991 - 1992. Washington, D.C.: Brassey's (US) Inc., 1991.

Bush, George W. Remarks during presidential debate at Wake Forest University, May 2000. On-line. Internet, 7 February 2002. Available from http://www.issues2000.org/George_W_Bush_Foreign_Policy.htm.

Chaveas, Peter R. Statement before the United States Senate Committee on Foreign Relations, 11 July 2001. On-line. Internet, 28 January 2002. Available from $\mathrm{http}: / /$ www.uspolicy.be/issues/AFRICA/s1071201.htm.

Cirafici, Lieutenant Colonel John L. Airhead Operations-Where AMC Delivers: The Linchpin of Rapid Force Projection. Maxwell AFB, Ala.: Air University Press, March 1995.

Clinton, William J. Presidential Decision Directive 25, U.S. Policy on Reforming Multilateral Peace Operations, 4 May 1994. On-line. Internet, 3 January 2002. Available from http://www.fas.org/irp/offdocs/pdd25.htm.

Cohen, Herman J. "U.S.-Africa Policy as Conflict Management." SAIS Review 21, no. 10 (Winter-Spring 2001): 230-244.

Coplin, William D. and Michael K. O'Leary, eds. Political Risk Yearbook 2001, volume 4, Sub-Saharan Africa. East Syracuse, N.Y.: The PRS Group, Inc., 2001.

Cunitz, Ronald R. "Applying Lessons Learned: the U.S. European Command Experience in Funding Operation Support Hope." Armed Forces Comptroller 40 (Win 95):15. 
Daalder, Ivo H. "Knowing When to Say No: the Development of U.S. Policy for Peace Keeping." In UN Peacekeeping, American Policy, and the Uncivil Wars of the 1990's. Edited by William J. Durch. N.Y.: St. Martin's Press, 1996.

Durch, William J. "Introduction to Anarchy: Humanitarian Intervention and 'State Building' in Somalia." UN Peacekeeping, American Policy, and the Uncivil Wars of the 1990's. Edited by William J. Durch. N.Y.: St. Martin's Press, 1996.

Feil, Scott R. Preventing Genocide: How the Early Use of Force Might Have Succeeded in Rwanda. N.Y.: Carnegie Corporation of New York, 1998.

Fleischman, Janet. "U.S.-Africa Policy as Human Rights." SAIS Review 21, no. 10 (Winter-Spring 2001): 245-258.

International Committee of the Red Cross. "Country Report Somalia: ICRC Worldwide Consultation on the Rules of War." People on War, 1999. On-line. Internet, 1 February 2002. Available from http://www.ifrc.org/icrceng.nsf.

Mandelbaum, Michael. "Foreign Policy as Social Work." Foreign Affairs (Jan/Feb 1996).

Minter, William. "The United States and Africa: Starting Points for a New Policy Framework." Global Focus. Edited by Martha Honey and Tom Barry. New York: St. Martin's Press, 255-281.

Mitchell, Alison. "U.S. Offers Troops for Mission to Aid Zaire Refugees." New York Times, 14 November 1996.

Reed, Pamela L., J. Matthew Vaccaro, and William J. Durch. Handbook on United Nations Peace Operations. Washington, D.C.: Henry L. Stimson Center, 1995.

Regional Surveys of the World: Africa South of the Sahara 2001. London: Europa Publications, 2000.

Reyntjens, Filip. "Briefing: The Democratic Republic of Congo, From Kabila to Kabila." African Affairs 100 (2001): 311-317.

Rice, Susan. Address. Columbia University, New York, N.Y., 20 October 1998. Online. Internet, 12 March 2002. Available from http://allafrica.com/stories/ 199810290188.htm.

Rothchild, Donald. "The U.S. Foreign Policy Trajectory on Africa." SAIS Review 21, no. 10 (Winter-Spring 2001): 179-207.

Rumsfeld, Donald. Quadrennial Dense Review. Washington, D.C.: Office of the Secretary of Defense, 20 September 2001.

Scowcroft, Brent. On-line, Internet, 17 February 2002. Available at http://www.sas.upenn.edu/African_Studies/Urgent_Action/APIC.

Sewall, Sarah. "U.S. Policy and Practice Regarding Multilateral Peace Operations." Carr Center for Human Rights Policy Working Paper 01-3. On-line. Internet, 1 February 2002. Available from http://www.ksg.harvard.edu/cchrp/web/Working/20papers/PKO.pdf.

Smith, Edwin P. "Joint Task Forces and Preemptive Response." Joint Force Quarterly 20 (Autumn/Winter 98-99): 91-99.

Smith, R. Jeffrey and Julia Preston. "United States Plans Wider Role in United Nations Peace Keeping." Washington Post, 18 June 1993. On-line. Internet, 1 February 2002. Available from http://www.fas.org/irp/offdocs/pdd13.htm. 
United Nations. "Convention on the Prevention and Punishment of the Crime of Genocide." United Nations Treaty Collection, October 2001. On-line. Internet, 8 February 2002. Available from http://www.unhcr.ch/html/menu3/b/p_genoci.htm. 